\title{
Genetic diversity analysis of Piper betle from eight accessions of Indonesia based on SRAP markers
}

\author{
SHARAH NABILLA ${ }^{1}$, UKHRADIYA MAGHARANIQ SAFIRA ${ }^{1}$, PUSPA JULISTIA PUSPITA ${ }^{1}$, \\ DYAH SUBOSITI ${ }^{2}$, ANSHARY MARUZY ${ }^{2}$, I MADE ARTIKA $^{1, \vee}$ \\ ${ }^{1}$ Department of Biochemistry, Faculty of Mathematics and Natural Sciences, Institut Pertanian Bogor. Jl. Tanjung, Kampus IPB Dramaga, Bogor 16680, \\ West Java, Indonesia. Tel.: +62-251-8423267, `email: imart@apps.ipb.ac.id \\ ${ }^{2}$ Medicinal Plant and Traditional Medicine Research and Development Centre, National Institute of Health and Research Development Indonesia. \\ Ministry of Health. J1. Raya Lawu No 11, Tawangmangu, Karanganyar 57792, Central Java, Indonesia
}

Manuscript received: 1 July 2021. Revision accepted: 24 July 2021.

\begin{abstract}
Nabilla S, Safira UM, Puspita PJ, Subositi D, Maruzy A, Artika IM. 2021. Genetic diversity analysis of Piper betle from eight accessions of Indonesia based on SRAP markers. Biodiversitas 22: 3401-3408. Leaves of betel vine (Piper betle Linn.) have been used as a traditional medicine in various regions in Indonesia. However, the genetic diversity of this plant has not been well recorded. Considering its diverse usage in traditional and folk medicine, it is essential to analyze and document the genetic diversity of Piper betle L. with the aim to collect the scientific data of betel vine genetics in Indonesia. This study aims at analyzing the population structure and genetic diversity of betel vine from the Singkil, Gayo Serbajadi, Baduy, Bandung, Hutan, Kalisusu, Kaledupa, and Mekongga accession groups of Indonesia using the sequence-related-amplified polymorphism (SRAP) marker technique. Genomic DNA was isolated from each accession and then used as a template for DNA amplification using PCR. As many as 16 SRAP primer combinations were screened for the genetic diversity analysis. Optimization of primer combinations resulted in 7 selected combinations based on their ability to generate clear amplification patterns and polymorphic bands. These were then employed for genetic diversity analysis. The genetic distance dendrogram showed the lowest similarity coefficient was 0.62 and that the betel vine grouping pattern was not based on genotype. The Singkil population had the highest genetic diversity and the Hutan population had the lowest. The mean value of Nei's genetic diversity index was 0.0985 , while Shannon's information index was 0.01459 and the percentage of polymorphic loci was 25.81 . This study concluded that the level of betel vine diversity is low.
\end{abstract}

Keywords: Betel vine, genetic diversity, Piper betle, SRAP

\section{INTRODUCTION}

Betel vine (Piper betle Linn.) is a perennial dioecious plant with leaves possessing numerous bioactive components (Patra and Pradhan 2018). It has been widely cultivated and used in traditional herbal medicines in many Asian countries, such as India, China, Taiwan, Thailand, Srilanka, Bangladesh, Burma, Nepal, Indonesia, etc. (Ali et al. 2010; Rai et al. 2011; Durani et al. 2017; Andrianto et al. 2020). Traditionally, betel vine leaves are used as a mouth freshener, an anthelmintic, an anti-allergic, an antiacne, in contraception and to treat eye infection and postpartum infection (Ghosh and Bhattacharya 2005; Andrianto et al. 2020). In addition, the leaves of Piper betle L. are also reported to have antioxidant, anti-inflammatory, anti-apoptotic, anti-cancer and anti-microbial activities (Das et al. 2016). Studies on profiling phenolic compounds of Piper betle L showed that the leaves of this plant contain twelve phenolic compounds, consisting of a phenylpropanoid, five cinnamoyl, and six flavonoids, with hydroxychavicol as the main compound (Ferreres et al. 2014).

Information on plant genetic diversity is very useful for the development of new or improved cultivars with more desirable characteristics (Govindaraj et al. 2015). In addition, genetic diversity analysis is important for our understanding of genetic traits, population genetics, molecular breeding and disease control programs ( $\mathrm{Li}$ et al. 2014). Several studies have been conducted in order to analyze the molecular genetic diversity of Piper betle L. For example, Verma et al. (2004) employed the random amplified polymorphic DNA (RAPD) method to analyze the genetic diversity of several Indian betel vine varieties. Based on eleven RAPD primers, they found that the varieties belonging to the Kapoori group were genetically the most diverse (Verma et al. 2004). Data on genetic diversity of Indonesian Piper betle L. are limited. The present study was aimed at analyzing the genetic diversity of Piper betle L. amongst 8 betel vine accessions from Indonesia based on sequence-related-amplifiedpolymorphism (SRAP) markers. SRAP markers have been used to amplify coding regions of DNA with primers targeting open reading frames. These markers are found to be robust, highly variable, and user-friendly. SRAP markers find wide applications in agronomic and horticultural fields as well as in the analysis of genetic diversity of large germplasm collections ( $\mathrm{Li}$ et al. 2014; Robarts and Wolfe 2014). 


\section{MATERIALS AND METHODS}

\section{Preparation of samples}

As many as 20 samples from 8 accessions, from 4 different regions of Indonesia (Table 1) were employed in this study. Samples of 0.04 to $0.05 \mathrm{~g}$ dry leaf were placed in a labelled zip-lock plastic bag. The samples were stored at $-20^{\circ} \mathrm{C}$ overnight or for 1 hour in an ultralow temperature freezer. Each sample was then ground using a sterile mortar and pestle.

\section{Isolation of DNA}

DNA isolation was carried out using the Thermo Scientific GeneJET Plant Genomic DNA Purification Mini Kit \#K0791, following the manufacturer's instructions. As much as 0.04-0.05 $\mathrm{g}$ of sample was ground in the presence of liquid nitrogen. After washing with STE solution (0.25 M sucrose, $0.03 \mathrm{M}$ Tris, $0.05 \mathrm{M}$ EDTA) or HEPES buffer, the mixture was centrifuged twice at $2000 \mathrm{x}$ g for $10 \mathrm{~min}$ followed by centrifugation at $3000 \mathrm{x}$ g for $5 \mathrm{~min}$. The pellet was transferred into a $1.5 \mathrm{~mL}$ microcentrifuge tube followed by the addition $350 \mu \mathrm{L}$ lysis buffer A, $50 \mu \mathrm{L}$ lysis buffer B and $20 \mu \mathrm{L}$ RNase A. The mixture was vortexed for $1 \mathrm{~min}$ followed by incubation at $65^{\circ} \mathrm{C}$ for $10 \mathrm{~min}$ with occasional vortexing. Then $130 \mu \mathrm{L}$ of precipitating solution was added and the mixture was homogenized, incubated in ice for $5 \mathrm{~min}$ and then centrifuged at $\geq 20.000 \mathrm{xg}$ for $5 \mathrm{~min}$. A $500 \mu \mathrm{L}$ of supernatant was transferred into a new microcentrifuge tube followed by the addition of $400 \mu \mathrm{L}$ plant gDNA-binding-solution and $400 \mu \mathrm{L}$ ethanol $96 \% \mathrm{v} / \mathrm{v}$. As much as $600 \mu \mathrm{L}$ of the mixture was transferred to the spin column and then centrifuged for 1 minute at $6000 \mathrm{x} \mathrm{g}$. The flow-through solution was discarded and the remaining mixture was applied onto the same column and centrifuged again for 1 minute at a speed of $6000 \mathrm{x} \mathrm{g}$ and the flowthrough was discarded. As much as $500 \mu \mathrm{L}$ of wash buffer I was added to the column followed by centrifugation at $8000 \mathrm{x} \mathrm{g}$ for $1 \mathrm{~min}$ and the flow-through solution was discarded. A total of $500 \mu \mathrm{L}$ of wash buffer II was added to the column followed by centrifugation. The flow-through solution was discarded and the purification column was placed back into the tube and re-spun for 3 minutes at a maximum of $\geq 20,000 \mathrm{x} \mathrm{g}$ and the flow-through solution was discarded. The column was inserted into a sterile 1.5 $\mathrm{mL}$ microcentrifuge tube. A total of $100 \mu \mathrm{L}$ of elution buffer was added to the middle of the column followed by incubation for 5 minutes at room temperature. The column was centrifuged for 1 minute at a speed of $8000 \mathrm{x} \mathrm{g}$. A second elution was performed in the same way. To determine purity, the absorbance of the isolated genomic DNA was measured at a wavelength of $260 \mathrm{~nm}$ and $280 \mathrm{~nm}$ $(\lambda 260 / 280)$. The DNA was stored at $-20^{\circ} \mathrm{C}$.

\section{Amplification of DNA}

DNA amplification was carried out using the polymerase chain reaction (PCR) technique employing SRAP primers. The SRAP primers used consisted of 4 forward primers (Me1-Me4) and 4 reverse primers (Em1Em4), as listed in Table 2. In this study, 16 primer combinations (Table 3 ) were generated and these were then screened for use in the analysis based on their ability to generate clear polymorphic bands from all of the betel vine accessions.

DNA amplification was conducted according to a modified method of Li and Quiros (2001). PCR was carried out in a $15 \mu \mathrm{l}$ reaction volume containing $1 \mu \mathrm{l}$ of DNA template DNA $(20 \mathrm{ng} / \mu \mathrm{l}), 0.7 \mu \mathrm{l}$ forward primer $(10-20$ $\mu \mathrm{M}), 0.7 \mu \mathrm{l}$ reverse primer $(20 \mu \mathrm{M}), 7.5 \mu \mathrm{l}$ PCR mixture, and $5.1 \mu \mathrm{l}$ nuclease-free water. Our PCR procedures included initial denaturation at $94^{\circ} \mathrm{C}$ for $5 \mathrm{~min}$, followed by denaturation at $94^{\circ} \mathrm{C}$ for $1 \mathrm{~min}$, phase I primer annealing at sequentially increasing temperature from $33.0^{\circ} \mathrm{C}, 33.7^{\circ} \mathrm{C}$, $35.2^{\circ} \mathrm{C}, 37.7^{\circ} \mathrm{C}, 40.5^{\circ} \mathrm{C}, 42.4^{\circ} \mathrm{C}, 44.0^{\circ} \mathrm{C}$, to $45.0^{\circ} \mathrm{C}$ for 1 $\mathrm{min}$, and primer extension at $72^{\circ} \mathrm{C}$ for $1 \mathrm{~min}$, which were conducted for 5 cycles. These were followed by the second PCR cycle with denaturation at $94^{\circ} \mathrm{C}$ for $1 \mathrm{~min}$ and phase II primer annealing at increasing temperature from $45^{\circ} \mathrm{C}$, $45.9^{\circ} \mathrm{C}, 47.5^{\circ} \mathrm{C}, 50.0^{\circ} \mathrm{C}, 53.0^{\circ} \mathrm{C}, 55.3^{\circ} \mathrm{C}, 57.0^{\circ} \mathrm{C}$, to $58^{\circ} \mathrm{C}$ for $1 \mathrm{~min}$, primer extension at $72^{\circ} \mathrm{C}$ for $1 \mathrm{~min}$, which was conducted for 35 cycles. The final step was to hold the reaction at $4^{\circ} \mathrm{C}$ for 15 min (modified from $\mathrm{Li}$ and Quiros 2001).

\section{Electrophoresis of DNA}

Separation of genomic DNA, or DNA fragments, was carried out essentially using a standard agarose-gel electrophoresis method (Montero-Campos et al. 2015; Lee et al. 2012). Genomic DNA was separated using $1 \%(\mathrm{w} / \mathrm{v})$ agarose gel at 100 Volts for $30 \mathrm{~min}$ in $45 \mathrm{mM}$ Tris-borate, 1 mM EDTA (TBE) running buffer. PCR products were separated using $2.5 \%(\mathrm{w} / \mathrm{v})$ agarose gel at 50 Volts for 60 min in TBE running buffer. DNA molecules were stained using PeqDye and visualization was conducted using a UV transillumination or Gel Doc ${ }^{\mathrm{TM}}$ EZ System.

Table 1. Samples used

\begin{tabular}{lll}
\hline Sample code & \multicolumn{1}{c}{ Accession } & \multicolumn{1}{c}{ Province } \\
\hline PB-AC-A1 & Singkil & Aceh \\
PB-AC-E1 & Singkil & Aceh \\
PB-AC-E2 & Singkil & Aceh \\
PB-AC-E3 & Singkil & Aceh \\
PB-AC-E4 & Singkil & Aceh \\
PB-AC-F1 & Gayo Serbajadi & Aceh \\
PB-AC-G1 & Gayo Serbajadi & Aceh \\
PB-RI-B1 & Hutan & Riau \\
PB-RI-B2 & Hutan & Riau \\
PB-JB-A2 & Baduy & West Java \\
PB-JB-A3 & Baduy & West Java \\
PB-JB-A4 & Baduy & West Java \\
PB-JB-B4 & Bandung & West Java \\
PB-LG-A1 & Kalisusu & Southeast Sulawesi \\
PB-LG-A4 & Kalisusu & Southeast Sulawesi \\
PB-LG-B2 & Kaledupa & Southeast Sulawesi \\
PB-LG-C1 & Mekongga & Southeast Sulawesi \\
PB-LG-C2 & Mekongga & Southeast Sulawesi \\
PB-LG-D1 & Mekongga & Southeast Sulawesi \\
PB-LG-D2 & Mekongga & Southeast Sulawesi \\
\hline
\end{tabular}


Table 2. SRAP primers used

\begin{tabular}{ccc}
\hline Primer code & Type & Primer sequence $\left(\mathbf{5}^{\prime} \rightarrow \mathbf{3}\right.$ ') \\
\hline Me1 & forward & TGA GTC CAA ACC CGA TA \\
Me2 & forward & TGA GTC CAA ACC CGA GC \\
Me3 & forward & TGA GTC CAA ACC CGA AT \\
Me4 & forward & TGA GTC CAA ACC CGA CC \\
Em1 & reverse & GAC TGC GTA CGA ATT AAT \\
Em2 & reverse & GAC TGC GTA CGA ATT TGC \\
Em3 & reverse & GAC TGC GTA CGA ATT GAC \\
Em4 & reverse & GAC TGC GTA CGA ATT TG \\
\hline
\end{tabular}

Table 3. SRAP primer combinations generated from the SRAP primer sets

\begin{tabular}{cccc}
\hline No. & $\begin{array}{c}\text { Primer } \\
\text { combination }\end{array}$ & No. & $\begin{array}{c}\text { Primer } \\
\text { combination }\end{array}$ \\
\hline 1 & Me1-Em1 & 9 & Me3-Em1 \\
2 & Me1-Em2 & 10 & Me3-Em2 \\
3 & Me1-Em3 & 11 & Me3-Em3 \\
4 & Me1-Em4 & 12 & Me3-Em4 \\
5 & Me2-Em1 & 13 & Me4-Em1 \\
6 & Me2-Em2 & 14 & Me4-Em2 \\
7 & Me2-Em3 & 15 & Me4-Em3 \\
8 & Me2-Em4 & 16 & Me4-Em4 \\
\hline
\end{tabular}

\section{Analysis of genetic diversity}

DNA fragments that were generated from each betel vine accession using each primer combination were measured and documented. The existence of bands from each betel vine accession was scored ( 1 for presence, 0 for absence). The similarity index was calculated using the Dice similarity index formula. Cluster analysis and dendrogram construction were carried out using the unweighted pair group method using the arithmetic mean (UPGMA). The coordinate principle of each individual was analyzed. Population genetic diversity was analyzed. Data obtained was analyzed using the NTSYS version 2.02 and PopGen 32 computer programs.

\section{RESULTS AND DISCUSSION}

\section{Concentration and purity of genomic DNA}

The concentration and level of purity of the isolated genomic DNA is shown in Table 4.

\section{Selected SRAP primer combination}

Sixteen SRAP primer combinations were screened based on their ability to generate a clear amplification pattern and show polymorphism in all betel vine tested using the gradient-PCR technique at various temperature combinations. Results showed that 7 primer combinations, i.e., combinations 2 (Me1-Em2), 3 (Me1-Em3), 5 (Me2Em1), 7 (Me2-Em3), 13 (Me4-Em1), 14 (M24-Em2), 15 (Me4-Em3) have the ability to amplify betel vine DNA and generate clear bands at various annealing temperatures as shown in Figure 1. These primer combinations were selected for genetic diversity analysis. The other combinations did not produce sufficiently clear bands.
When primer combinations 5, 6, and 7 were further tested using sample PB-LG-C1, the results were consistent, in that, primer combinations 5 and 7 generated clear polymorphic bands while primer combination 6 did not. Primer combination 5 generated bands at annealing temperatures of $42.4^{\circ} \mathrm{C}$ and $55.3^{\circ} \mathrm{C}$. Similarly, primer combination 7 generated bands at annealing temperatures of $45.0^{\circ} \mathrm{C}$ and $58.0^{\circ} \mathrm{C}$ (Figure 2).

\section{Genetic diversity based on SRAP markers}

The extent of genetic diversity of the betel vine was revealed by the 7 selected SRAP primer combinations. The number of bands generated by each primer combination ranged from 3 to 7 . The size of the bands ranged from 75 to 700 bp. The total bands generated by the 7 primer combinations were 31 with average 3.43 bands produced by each primer combination. The total polymorphic bands produced were 24 with average 3.43 polymorphic bands generated by each primer combination. The polymorphic bands were identified based on their size. It was observed that the proportion of the polymorphic bands was consistently above $66.7 \%$. Among the primer combinations employed, primer combination 7 generated the highest level of polymorphic bands, being $85.71 \%$. Overall, the primer used generated an average of polymorphic bands of $74.86 \%$ as shown in Table 5.

The number of amplifiable amplicons ranging from 3-7, with a mean of 4.43 amplicons per primary combination (Table 5) was lower than the study conducted by Bhatt et al. (2017). These results indicated that there was a substantial amount of unamplified polymorphism at the SRAP locus studied.

Table 4. Concentration and purity of isolated genomic DNA from betel vine

\begin{tabular}{lcc}
\hline Sample code & $\begin{array}{c}\text { DNA Concentration } \\
(\mathbf{n g} / \boldsymbol{\mu L})\end{array}$ & Purity $\left(\mathbf{A}_{\mathbf{2 6 0} / 280}\right)$ \\
\hline PB-AC-A1 & 7.3 & 2.39 \\
PB-AC-E1 & 48.2 & 1.98 \\
PB-AC-E2 & 23.6 & 1.95 \\
PB-AC-E3 & 57.4 & 1.92 \\
PB-AC-E4 & 72.1 & 1.87 \\
PB-AC-F1 & 40.6 & 1.92 \\
PB-AC-G1 & 58.6 & 1.75 \\
PB-RI-B1 & 5.4 & 2.36 \\
PB-RI-B2 & 13.3 & 1.77 \\
PB-JB-A2 & 56.6 & 1.87 \\
PB-JB-A3 & 42.8 & 1.94 \\
PB-JB-A4 & 85.0 & 1.82 \\
PB-JB-B4 & 83.0 & 1.80 \\
PB-LG-A1 & 70.2 & 1.80 \\
PB-LG-A4 & 48.4 & 1.89 \\
PB-LG-B2 & 63.8 & 1.80 \\
PB-LG-C1 & 123.4 & 1.77 \\
PB-LG-C2 & 106.3 & 1.79 \\
PB-LG-D1 & 91.9 & 1.78 \\
PB-LG-D2 & 94.4 & 1.73 \\
\hline
\end{tabular}



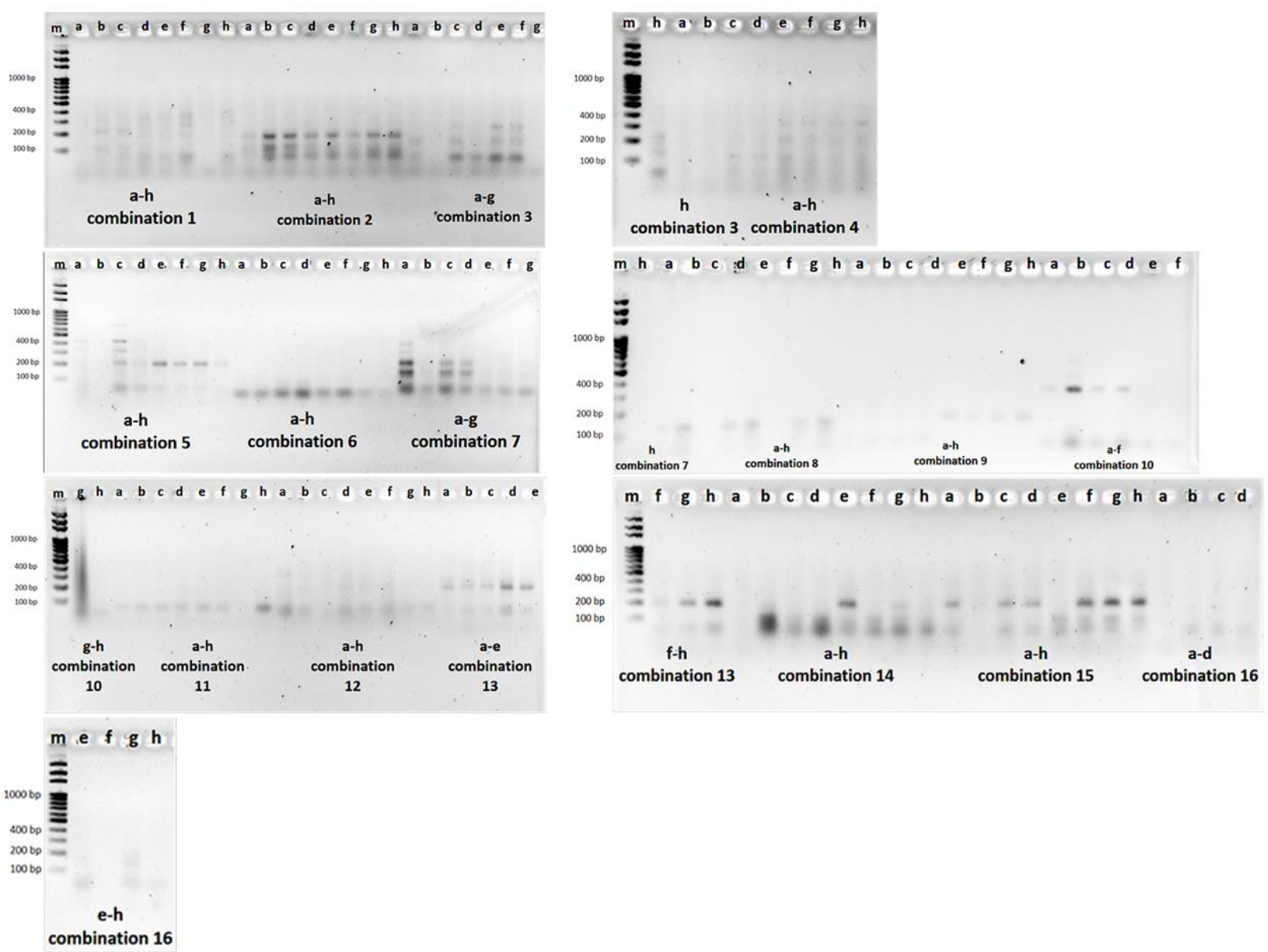

Figure 1. Electrophoregrams showing optimization of PCR conditions for 16 SRAP primer combinations. a: annealing temperature I $45.0^{\circ} \mathrm{C}$, annealing temperature II $58.0^{\circ} \mathrm{C}$; b: annealing temperature I $44.0^{\circ} \mathrm{C}$, annealing temperature II $57.0^{\circ} \mathrm{C}$; c: annealing temperature I $42.4^{\circ} \mathrm{C}$, annealing temperature II $55.3^{\circ} \mathrm{C}$; d: annealing temperature I $40.5^{\circ} \mathrm{C}$, annealing temperature II $53.0^{\circ} \mathrm{C}$; e: annealing temperature I $37.7^{\circ} \mathrm{C}$, annealing temperature II $50.0^{\circ} \mathrm{C}$; f: annealing temperature I $35.0^{\circ} \mathrm{C}$, annealing II $47.5^{\circ} \mathrm{C}$; g: annealing temperature I $33.7^{\circ} \mathrm{C}$, annealing temperature II $45.9^{\circ} \mathrm{C}$; h: annealing temperature I $33.0^{\circ} \mathrm{C}$, annealing temperature $\mathrm{II} 45.0^{\circ} \mathrm{C}$.

The number of DNA bands amplified from the PCR technique was 31 bands, with 24 polymorphic bands. Polymorphism results from the variations in the DNA sequences and it is positively correlated with genetic diversity (Abdelaziz et al. 2020). In addition, high polymorphism obtained indicates that the techniques used in evaluating the samples genetic diversity are efficient (Hamouda 2019). The most informative primary combination among the 7 primary combinations used was the combination of 7 and 2 with the resulting polymorphic band percentage of $85.71 \%$ and $83.33 \%$ respectively (Table 5 ). The primer that amplified the most was primer 7 (Figure 3). The electropherogram was then translated into binary form (Table 6). Code 1 designates the occurrence of DNA bands and code 0 the absence of bands.

\section{Genetic diversity based on a selected SRAP primer combination}

As primer combination 7 produced the most polymorphic bands, it was further tested using samples PBJB-A3, PB-AC-E1 and PB-AC-E4. Results of PCR amplification are shown in Figure 3. The amplicon bands were then translated into binary codes, 1 for presence and 0 for absence of bands as shown in Table 6 .

\section{Genetic relationship of betel vine based on SRAP marker (cluster analysis)}

Results for the betel vine accessions genetic relationship showed the genetic similarity coefficients ranged from 0.62 to 0.94 . This indicated that the genetic diversity of the betel vine ranged from 6 to $38 \%$. The genetic similarity of the betel vine formed two major groups, group I and II, with coefficients of 0.62 and 0.724 respectively. The two groups consisted of 3 distinct clusters, A, B, and C as shown in Figure 4. Group I consisted of two small clusters (A and B) and group II consisted of one cluster (C). Group A includes 10 populations from 5 regions, Aceh, Riau, West Java, and Sulawesi. Group B consisted of 4 populations from Sulawesi. Group C consisted of 6 populations from West Java and Aceh. Principal Component Analysis showed that the 20 betel vine populations formed 3 main clusters, A, B, and C, with cumulative diversity values of $84.20 \%$ (PC1 $73.61 \%$ and PC2 10.59\%). As shown in Figure 5. 


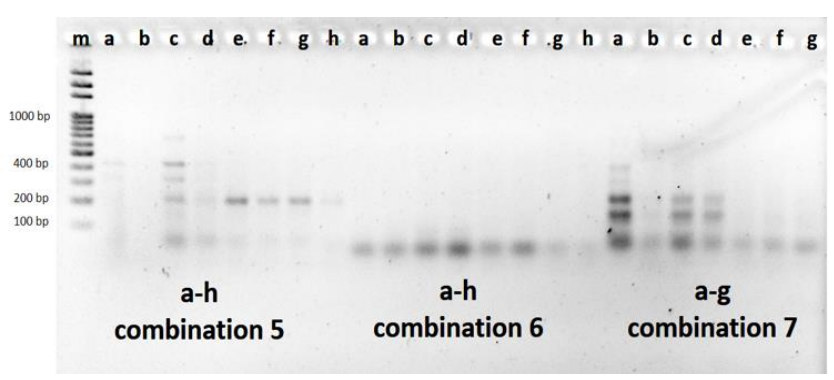

Figure 2. Electrophoregram of PCR products for temperature optimization of primer combinations 5, 6 and 7. Annealing temperature (a) (I:45. $0^{\circ} \mathrm{C}$, II:58.0 $\left.{ }^{\circ} \mathrm{C}\right)$; (b) $\left(\mathrm{I}: 44.0^{\circ} \mathrm{C}\right.$, II:57.0 $\left.0^{\circ} \mathrm{C}\right) ;(\mathrm{c})$ (I:42. $4^{\circ} \mathrm{C}$, II:55.3 $\left.{ }^{\circ} \mathrm{C}\right) ;$ (d) $\left(\mathrm{I}: 40.5^{\circ} \mathrm{C}, \quad\right.$ II:53.0 $\left.{ }^{\circ} \mathrm{C}\right) ;$ (e) $\left(\mathrm{I}: 37.7^{\circ} \mathrm{C}\right.$, II:50.0 $\left.{ }^{\circ} \mathrm{C}\right)$; (f) $\left(\mathrm{I}: 35.2^{\circ} \mathrm{C}\right.$, II: $\left.47.5^{\circ} \mathrm{C}\right) ;(\mathrm{g})\left(\mathrm{I}: 33.7^{\circ} \mathrm{C}\right.$, II: $\left.45.9^{\circ} \mathrm{C}\right) ;(\mathrm{h})$ (I:33. $0^{\circ} \mathrm{C}$, II: $45.0^{\circ} \mathrm{C}$ ).

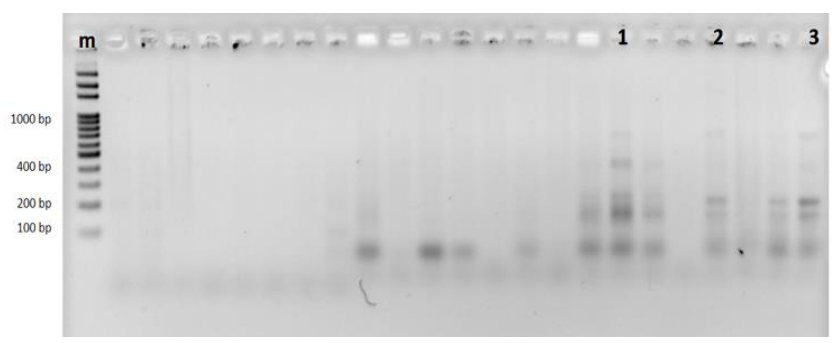

Figure 3. Electropherogram of PCR amplicons of samples $\mathrm{PB}$ JB-A3 (1), PB-AC-E (2) and PB-AC-E4 (3) using primer combination 7. The genomic DNA of the samples PB-JB-A3, PBAC-E1 and PB-AC-E4 were isolated using the Thermo Scientific GeneJET Plant Genomic DNA Purification Mini Kit \#K0791. Each of the isolated genomic DNA samples was used as a template for SRAP PCR amplification using primer combination 7.

Table 5. Profile of bands generated from PCR amplification of seven primer combinations using SRAP markers

\begin{tabular}{lcccc}
\hline $\begin{array}{c}\text { Primer } \\
\text { combination }\end{array}$ & $\begin{array}{c}\text { Band } \\
\text { size } \\
\text { (bp) }\end{array}$ & $\begin{array}{c}\text { No. of } \\
\text { bands }\end{array}$ & $\begin{array}{c}\text { No. of } \\
\text { polymorphic } \\
\text { bands }\end{array}$ & $\begin{array}{c}\text { Percentage of } \\
\text { polymorphic } \\
\text { band (\%) }\end{array}$ \\
\hline 2 & $75-260$ & 6 & 5 & 83.33 \\
3 & $75-140$ & 3 & 2 & 66.67 \\
5 & $75-600$ & 5 & 4 & 80.00 \\
7 & $75-700$ & 7 & 6 & 85.71 \\
13 & $75-200$ & 3 & 2 & 66.67 \\
14 & $75-200$ & 3 & 2 & 66.67 \\
15 & $75-200$ & 4 & 3 & 75.00 \\
Total & & 31 & 24 & 74.86 \\
Average & & 4.43 & 3.43 & \\
\hline
\end{tabular}

Clustering using principal component analysis (PCA) supported the results of analysis using statistical software NTSYSpc version 2.02 which grouped the samples into the 3 clusters A, B, and C. Cluster A featured the generation of bands (75 bp) by all primer combinations. Cluster B produced bands by primer combinations 2 (80 and $150 \mathrm{bp}$ ), 13 (80 and $200 \mathrm{bp}$ ), and 15 (200 bp). Cluster $\mathrm{C}$ generated bands by primer combination 5 (200 bp), 7 (80, 150 and 210 bp), 13 (200 bp), 14 (100 and 200 bp) and 15 (200 bp). Both dendrogram and matrix plot formed 3 clusters regardless of the sample origin.

The data in Figure 4 shows the lowest morphological similarity coefficient (0.94) with the farthest genetic distance $(0.62)$ resulting in a diversity percentage that was low $(38 \%)$. Low diversity can be due to the similarity of genotype species and vegetative reproduction. The highest similarity coefficient (0.94) was in the two genotypes originating from the Hutan ethnic group and the other two genotypes originated from the Mekongga accession. A small genetic distance indicates that the individual is closely related. Another genetic distance (0.94) was also found in one genotype originating from the Gayo Serbajadi and Singkil ethnic groups. However, another sample that also comes from Singkil is in sub-group $\mathrm{C}$ and has a close relationship with Baduy.

The PCA results support the phylogenetic tree by forming 3 large groups (Figure 5). The fact that the grouping of the 3 major PCA groups is not based on the geographic origin of the genotype. This result is in line with a study by Xiang et al. (2020) who used PCA based on SRAP amplification results in analyzing genetic diversity of Distylium chinense. Principal Component Analysis supports the result of the UPGMA clustering above.

Genetic diversity within a plant population can occur even if plant material comes from the same accession. Location differences as to where it grows can affect the diversity of plant species genetically, morphologically, and the content of active compounds (Wu et al. 2013). Betel vine originating from Aceh, the Singkil ethnic group, is grouped with betel vine from West Java, the Baduy accession means that the two accessions are genetically the same but have different names. This might be caused by genetic drift, local adaptation, and founder effect processes (Kumar and Agrawal 2019).

\section{Population genetic structure of betel vine of Indonesia}

The variations observed between the populations could be influenced by the fluctuating macro and microclimatic habitat conditions (Agarwal et al. 2019). Parameters of the genetic structure analysis include the number of different alleles $(\mathrm{Na})$, the number of effective alleles, Nei genetic diversity $(h)$, the value of Shanon information index (I) and the percentage of polymorphic loci (PPL). The results of the population genetic structure as analyzed using PopGen 32 are shown in Table 7.

Table 6. Binary profile of PCR amplification products using SRAP primer combination 7

\begin{tabular}{lccccccc}
\hline Sample & $\mathbf{1}(\mathbf{7 0 0} \mathbf{b p})$ & $\mathbf{2 ( 4 1 0} \mathbf{b p})$ & $\mathbf{3}(\mathbf{2 1 0} \mathbf{b p})$ & $\mathbf{4}(\mathbf{2 0 0} \mathbf{b p})$ & $\mathbf{5}(\mathbf{1 5 0} \mathbf{b p})$ & $\mathbf{6}(\mathbf{8 0} \mathbf{b p})$ & $\mathbf{7}(\mathbf{7 5} \mathbf{b p})$ \\
\hline PB-JB-A3 & 1 & 1 & 1 & 0 & 1 & 1 & 1 \\
PB-AC-E1 & 1 & 1 & 1 & 0 & 1 & 1 & 1 \\
PB-AC-E4 & 1 & 1 & 1 & 0 & 1 & 1 & 1 \\
\hline
\end{tabular}




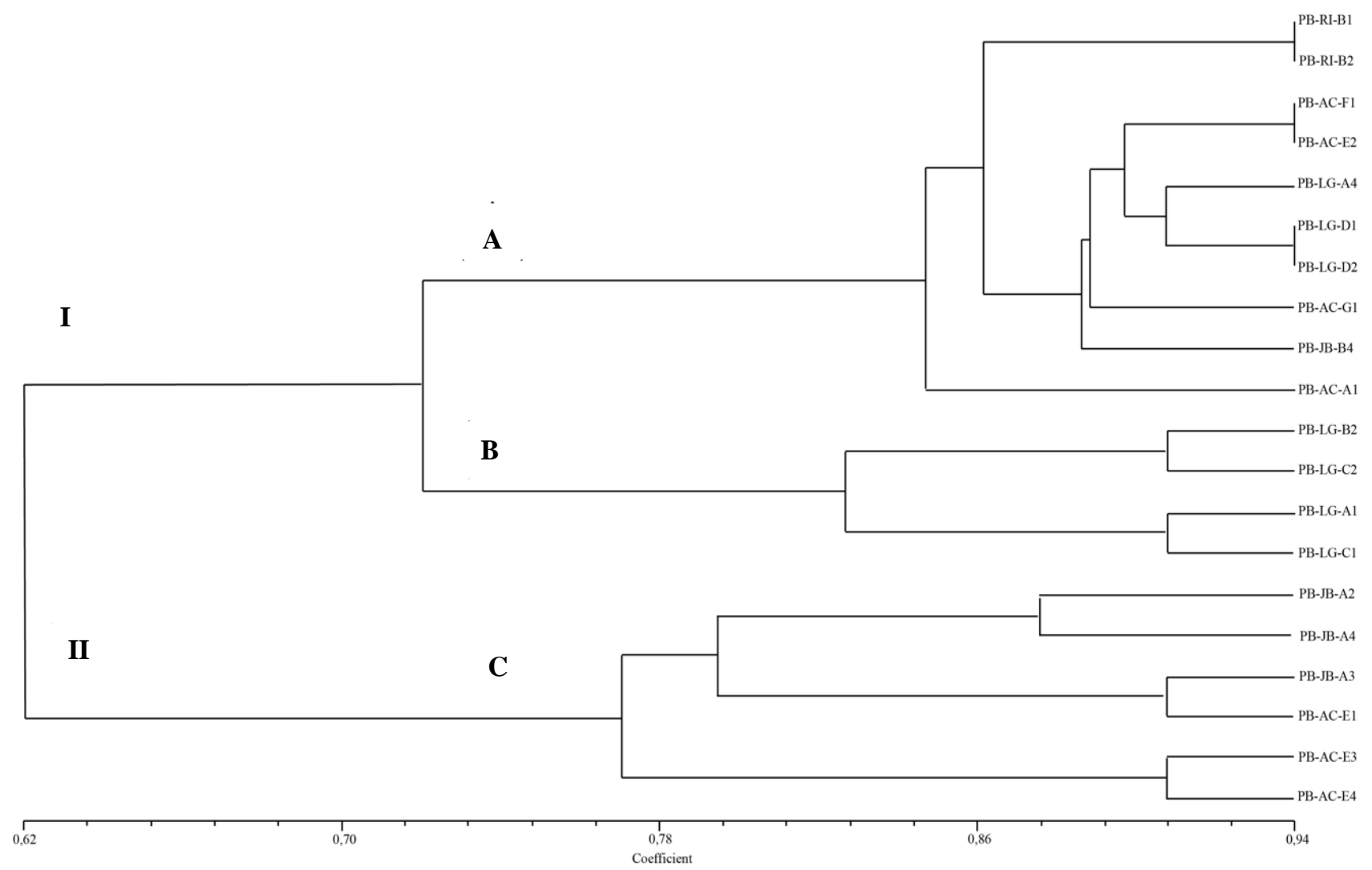

Figure 4. Phylogenetic tree for the twenty populations of Piper betle based on SRAP markers using the UPGMA method

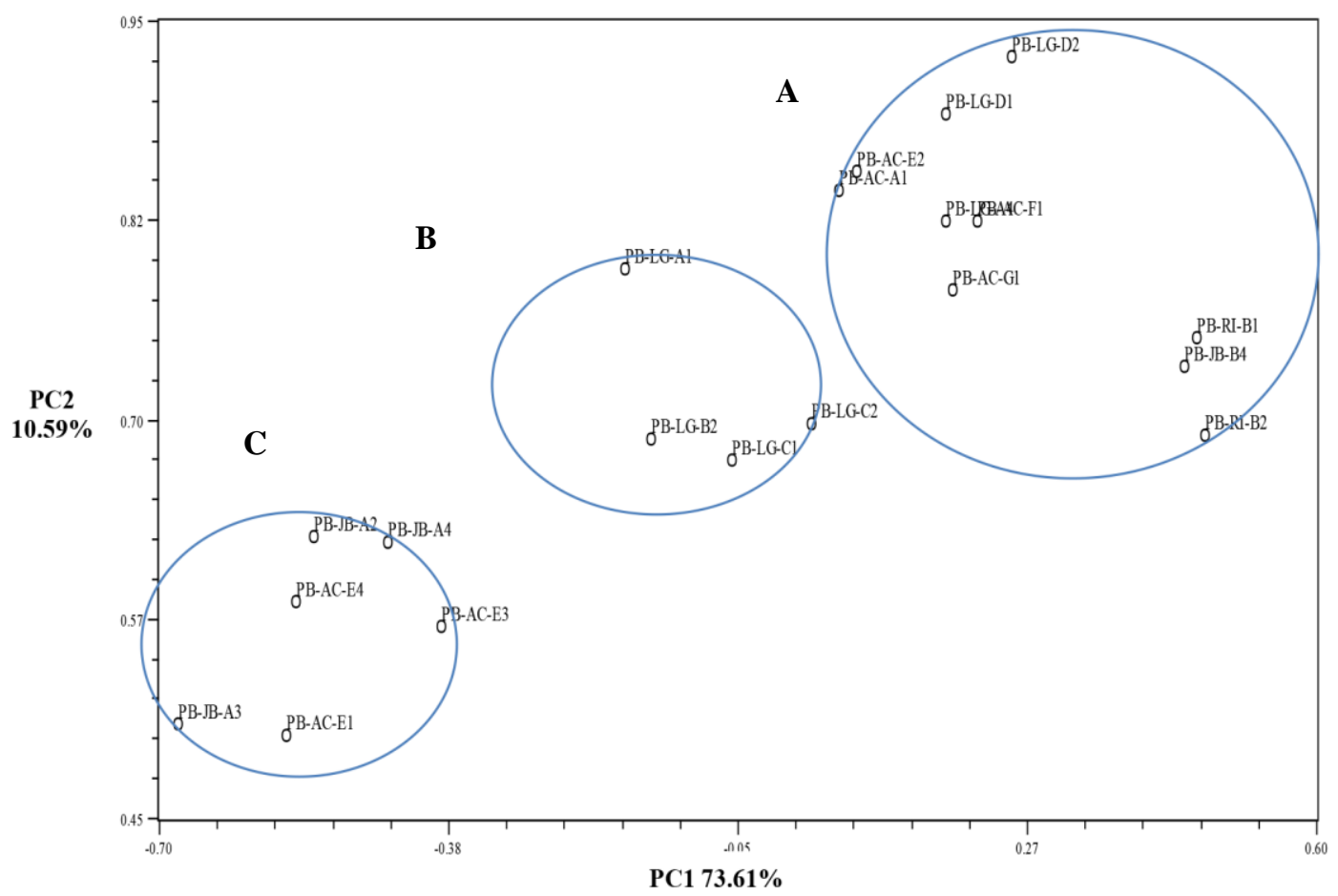

Figure 5. Matrix plot of principal component analysis of 20 betel vine populations using selected SRAP primer combinations 
Table 7. Population genetic structure of six betel vine population of Indonesia

\begin{tabular}{llcccccc}
\hline ID & Population & $\mathbf{N}$ & $\boldsymbol{N a}$ & $\boldsymbol{N e}$ & $\boldsymbol{H}$ & $\boldsymbol{I}$ & $\boldsymbol{P P L}(\boldsymbol{\%})$ \\
\hline 1 & Hutan (Riau) & 2 & 1.0642 & 1.0456 & 0.0267 & 0.0390 & 6.45 \\
2 & Singkil (Aceh) & 5 & 1.5161 & 1.3466 & 0.2007 & 0.2957 & 51.61 \\
3 & Gayo Serbajadi (Aceh) & 2 & 1.1290 & 1.0912 & 0.0534 & 0.0780 & 12.90 \\
4 & Baduy (West Java) & 3 & 1.2258 & 1.1644 & 0.0920 & 0.1340 & 22.58 \\
5 & Kalisusu (Southeast Sulawesi) & 2 & 1.2258 & 1.1597 & 0.0935 & 0.1366 & 22.58 \\
6 & Mekongga (Southeast Sulawesi) & 4 & 1.3871 & 1.2012 & 0.1247 & 0.1922 & 38.71 \\
Mean & & 3 & 1.2580 & 1.1681 & 0.0985 & 0.1459 & 25.81 \\
\hline
\end{tabular}

Note: N: number of individuals; $\mathrm{Na}$ : number alleles analyzed; $\mathrm{Ne}$ : number of effective alleles; $H$ : Nei's genetic diversity; $I$ : Shannon's information index, and PPL: percentage of polymorphic loci

Table 8. Value of Nei's genetic distance six betel vine population of Indonesia

\begin{tabular}{|c|c|c|c|c|c|c|}
\hline ID Population & 1 & 2 & 3 & 4 & 5 & 6 \\
\hline 1 & $* * * *$ & & & & & \\
\hline 2 & 0.2699 & $* * * *$ & & & & \\
\hline 3 & 0.1262 & 0.1958 & $* * * *$ & & & \\
\hline 4 & 0.5921 & 0.1310 & 0.3688 & $* * * *$ & & \\
\hline 5 & 0.1590 & 0.1284 & 0.1219 & 0.3338 & $* * * *$ & \\
\hline 6 & 0.1334 & 0.1321 & 0.1164 & 0.3124 & 0.0597 & $* * * *$ \\
\hline
\end{tabular}

Note: Populations: 1. Hutan; 2. Singkil; 3. Gayo Serbajadi; 4. Baduy; 5. Kalisusu; 6. Mekongga

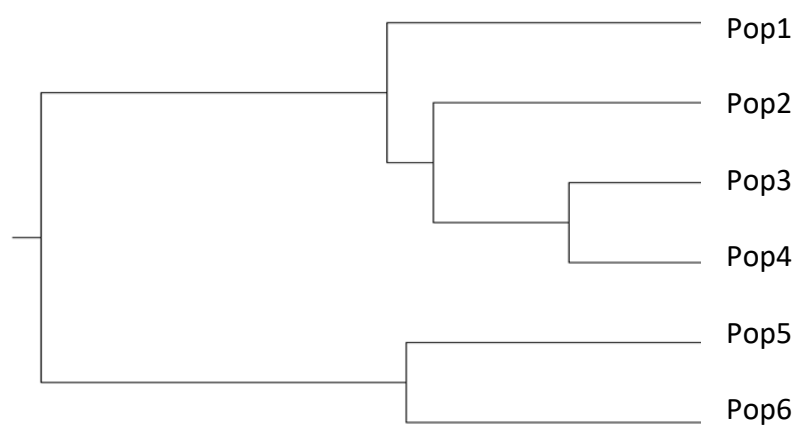

Figure 6. Dendrogram of genetic relationship between betel vine populations of Indonesia. Note: 1. Hutan; 2. Singkil; 3. Gayo Serbajadi; 4. Baduy; 5. Kalisusu; 6. Mekongga; pop: population.

Samples from Bandung and Kaledupa were not analyzed as each sample consists of only one individual so that did not meet our population criteria. The value of the observed number of alleles $(\mathrm{Na})$ (mean 1.2580) was higher than the value of the number of effective alleles $(\mathrm{Ne})$ (mean 1.1681). The Na value ranged from 1.0642 to 1.5161 . The highest $\mathrm{Na}$ value, which indicates the highest number of different alleles, was shown in the Singkil population, while the lowest $\mathrm{Na}$ value was detected in the Hutan population. The $\mathrm{Ne}$ value ranged from 1.0456 to 1.3466 . The highest value of Nei's gene diversity $(H=0.2007)$ was shown by the Singkil population, while the lowest value $(H=0.0267)$ was shown by the Hutan population. Similarly, the value of Shannon's information index was highest $(I=0.2957)$ in the Singkil population and lowest (I= 0.090) in the Hutan population. The percentage of polymorphic loci was also highest $(P P L=51.61 \%)$ in the Singkil population and lowest $(P P L=6.45 \%)$ in the Hutan population.
The value of the Nei's genetic distance indicates the relatedness between populations. Results showed that the Nei's genetic distance ranged from 0.0597 to 0.5921 . Kalisusu and Mekongga populations showed lowest genetic distance (0.0597) while Hutan and Baduy populations showed highest genetic distance (0.5921) (Table 8). These values were supported by the dendrogram data which showed that Hutan and Baduy populations showed the most distant genes while Kalisusu and Mekongga populations showed the closest genetic relationship (Figure 6).

We report genetic diversity of betel vine plant leaves collected from 8 different accessions of Indonesia analyzed using DNA-based sequence-related-amplifiedpolymorphism (SRAP) molecular markers. Genomic DNA of each sample was successfully extracted using the GeneJET $^{\mathrm{TM}}$ plant genomic DNA purification kit which was designed using a silica membrane for the isolation and purification of genomic DNA from a wide variety of plant species. This method has also been applied for isolation of genomic DNA from sorghum (Sorghum bicolor L. Moench) stem and root tissues (Maropola et al. 2015) as well as from pathogenic fungi of the family Fusarium proliferatum (Ferrara et al. 2019).

\section{ACKNOWLEDGEMENTS}

We acknowledge the Medicinal Plant and Traditional Medicine Research and Development Centre, National Institute of Health and Research Development, Ministry of Health, Republic of Indonesia, for supporting this study through the RISTOJA 2018 Program. We wish to thank the Department of Biochemistry, Bogor Agricultural University, Indonesia for providing research facilities. We also thank Dr. John Acton for their assistance with the manuscript. 


\section{REFERENCES}

Abdelaziz SM, Medraoui L, Alami M, Pakhrou O, Makkaoui M, Boukhary AOMS, Maltouf A. 2020. Inter simple sequence repeat markers to assess genetic diversity of the desert date (Balanites aegyptiaca Del.) for Sahelian ecosystem restoration. Sci Rep 10 (1): 14948. DOI: 10.1038/s41598-020-71835-9.

Agarwal A, Gupta V, Haq S, Jatav PK, Kothari SL, Kachhwaha S. 2019 Assessment of genetic diversity in 29 rose germplasms using SCoT marker. J King Saud Univ Sci 31: 780-788. DOI: 10.1016/j.jksus.2018.04.022.

Ali I, Khan FG, Suri KA, Gupta BD, Satti NK, Dutt P, Arifin F, Qazi GN, Khan IA. 2010. In vitro antifungal activity of hydroxychavicol isolated from Piper betle L. Ann Clin Microbiol Antimicrob 9 (7): 1 9. DOI: 10.1186/1476-0711-9-7.

Andrianto D, Husnawati, Hermita S, Haryanti S. 2020. Classification of betel leaves (Piper betle) from 15 ethnics in eastern Indonesia based on phytochemical fingerprint analysis. Biodiversitas 21 (1): 252-257. DOI: $10.13057 /$ biodiv/d210133.

Bhatt J, Kumar S, Patel S, Solanki R. 2017. Sequence-related amplified polymorphism (SRAP) markers based genetic diversity analysis of cumin genotypes. Ann Agrar Sci 15 (4): 434-438. DOI: 10.1016/j.aasci.2017.09.001.

Das S, Parida R, Sandeep IS, Nayak S, Mohanty S. 2016 Biotechnological intervention in betel vine (Piper betle L.): A review on recent advances and future prospects. Asian Pac J Trop Med 9 (10): 938-946. DOI: 10.1016/j.apjtm.2016.07.029.

Durani LW, Khor SC, Tan JK, Chua KH, Yusof YAM, Makpol S. 2017. Piper betle L. modulates senescence-associated genes expression in replicative senescent human diploid fibroblasts. BioMed Res Int $l$ 2017: 6894026. DOI: 10.1155/2017/6894026.

Ferrara M, Haidukowski M, Logrieco AF, Leslie JF, Mulè G. 2019. A CRISPR-Cas9 System for genome editing of Fusarium proliferatum. Sci Rep 9: 19836. DOI: 10.1038/s41598-019-56270-9.

Ferreres F, Oliveira AP, Gil-Izquierdo A, Valentão P, Andrade PB. 2014 Piper betle leaves: Profiling phenolic compounds by HPLC/DAD ESI/MSn and anti-cholinesterase activity. Phytochem Anal 25 (5): 453-460. DOI: 10.1002/pca.2515.

Ghosh K, Bhattacharya TK. 2005. Chemical constituents of Piper betle Linn. (Piperaceae) roots. Molecules 10 (7): 798-802. DOI: 10.3390/10070798

Govindaraj M, Srinivasan M, Vetriventhan M. 2015. Importance of genetic diversity assessment in crop plants and its recent advances: An overview of its analytical perspectives. Genet Res Int 2015: 431487. DOI: 10.1155/2015/431487.

Montero-Campos V, Arias-Cordero S, Valdés-Rodríguez B, JarquínCordero M. 2015. Quantitative detection of Helicobacter pylori by real time PCR in drinking water-environmental and public health risk significance. J Med Microbiol 5: 118-127. DOI 10.4236/ojmm.2015.53015.
Hamouda M. 2019. Molecular analysis of genetic diversity in population of Silybum marianum (L.) Gaertn in Egypt. J Genet Eng Biotechnol 17 (12) : 1-9. DOI: 10.1186/s43141-019-0011-6.

Kumar J, Agrawal V. 2019. Assessment of genetic diversity, population structure and sex identification in dioecious crop, Trichosanthes dioica employing ISSR, SCoT and SRAP markers. Heliyon 5 (3): e01346. DOI: 10.1016/j.heliyon.2019.e01346.

Lee PY, Costumbrado J, Hsu CY, Kim YH. 2012. Agarose gel electrophoresis for the separation of DNA fragments. J Vis Exp 62: 3923. DOI: $10.3791 / 3923$

Li G, Quiros CF. 2001. Sequence-related amplified polymorphism (SRAP), a new marker system based on a simple PCR reaction: Its application to mapping and gene tagging in Brassica. Theor Appl Genet 103: 455-461. DOI: 10.1007/s001220100570.

Li XY, Li J, Zhao ZJ, Yang F, Fu QW, Liu HS, Wang DD, Yang YC, Wang YR. 2014. Sequence-related amplified polymorphism (SRAP) for studying genetic diversity and population structure of plants and other living organisms: A protocol. J Anim Plant Sci 24 (5):14781486

Maropola MK, Ramond JB, Trindade M. 2015. Impact of metagenomic DNA extraction procedures on the identifiable endophytic bacterial diversity in Sorghum bicolor (L. Moench). J Microbiol Methods 112: 104-117. DOI: 10.1016/j.mimet.2015.03.012.

Patra B, Pradhan SN. 2018. A study on socio-economic aspects of betel vine cultivation of Bhogarai area of Balasore district, Odisha. J Exp Sci 9: 13-17. DOI: 10.25081 /jes.2018.v9.3651.

Rai MP, Thilakchand KR, Palatty PL, Rao P, Rao S, Bhat HP, Baliga MS. 2011. Piper betle Linn (betel vine), the maligned Southeast Asian medicinal plant possesses cancer-preventive effects: Time to reconsider the wronged opinion. Asian Pac J Cancer Prev 12 (9): 2149-2156.

Robarts DWH, Wolfe AD. 2014. Sequence-related amplified polymorphism (SRAP) markers: A potential resource for studies in plant molecular biology. Appl Plant Sci 2 (7): 1-13. DOI: 10.3732/apps. 1400017

Verma A, Kumar N, Ranade SA. 2004. Genetic diversity amongst landraces of a dioecious vegetatively propagated plant, betel vine (Piper betle L). J Biosci 29: 319-328. DOI: 10.1007/BF02702614.

Wu YB, Zheng LJ, Yi J, Wu JG, Chen TQ, Wu JZ. 2013. Quantitative and chemical fingerprint analysis for the quality evaluation of Receptaculum Nelumbinis by RP-HPLC coupled with hierarchical clustering analysis. Intl J Mol Sci 14 (1): 1999-2010. DOI: 10.3390/ijms14011999.

Xiang L, Li XL, Wang XS, Yang J, Lv K, Siong ZQ, Chen FQ, Huang CM. 2020. Genetic diversity and population structure of Distylium chinense revealed by ISSR and SRAP analysis in the Three Gorges Reservoir Region of the Yangtze River, China. Glob Ecol Conserv 21: e00805. DOI: 0.1016/j.gecco.2019.e00805. 